\title{
PURIFIKASI PARSIAL DAN KARAKTERISASI $\beta$-GALAKTOSIDASE Lactobacillus plantarum B123 INDIGENOS DAN HIDROLISIS LAKTOSA UNTUK PRODUKSI SUSU ULTRA HIGH TEMPERATURE RENDAH LAKTOSA
}

\section{PARTIAL PURIFICATION AND CHARACTERIZATION $\beta$-GALACTOSIDASE Lactobacillus plantarum B123 INDIGENOS AND LACTOSE HYDROLISIS TO PRODUCE LOW LACTOSE ULTRA HIGH TEMPERATURE MILK}

\author{
Tatik Khusniati $^{1}$, Neny Mariyani ${ }^{2}$, Hanifah Nuryani Lioe ${ }^{2}$, Didah Nur Faridah ${ }^{2}$, Abdul Choliq ${ }^{1}$ \\ Dan Sulistiani ${ }^{1}$ \\ ${ }^{1}$ Bidang Mikrobiologi, Pusat Penelitian Biologi, \\ Lembaga Ilmu Pengetahuan Indonesia. \\ ${ }^{2}$ Departemen Teknologi Pangan, FATETA, Universitas Pertanian Bogor \\ Email: tatikkhusni@yahoo.com
}

Diterima : 08 September 2015, Revisi : 22 Oktober 2015, Disetujui : 14 Nopember 2015

\section{ABSTRAK}

$\beta$-Galaktosidase merupakan enzim penghidrolisis laktosa menjadi glukosa dan galaktosa. Enzim ini digunakan dalam produksi susu rendah laktosa untuk konsumsi penderita intoleransi laktosa. Purifikasi parsial $\beta$-galaktosidase penting dilakukan untuk meningkatkan aktivitas $\beta$ galaktosidase sehingga potensi hidrolisinya pada laktosa susu Ultra High Temperature meningkat. Penelitian ini bertujuan untuk produksi dengan purifikasi parsial dan karakterisasi $\beta$-galaktosidase Lactobacillus plantarum B123 indigenos dan hidrolisis laktosa untuk produksi susu UHT rendah laktosa. Purifikasi parsial dilakukan dengan pengendapan yang diikuti dialisis. Karakterisasi meliputi optimasi dan stabilitas enzim, sedangkan hidrolisis laktosa untuk produksi susu UHT rendah laktosa dideteksi menggunakan kit enzimatik GODPOD. Hasil penelitian menunjukkan bahwa produksi $\beta$-galaktosidase dengan purifikasi parsial mengalami peningkatan dari $21.51 \pm 0.23 \mathrm{U} / \mathrm{mL}$ (kasar) menjadi $106.34 \pm 0.56 \mathrm{U} / \mathrm{mL}$ (dialisis). Aktivitas $\beta$-galaktosidase kasar optimum tercapai pada pengendapan amonium sulfat dengan konsentrasi $60 \%$. Kemurnian $\beta$-galaktosidase kasar meningkat sebesar 3.71 kali setelah pengendapan, dan 14.28 kali setelah dialisis. Karakterisasi $\beta$ galaktosidase menunjukkan bahwa aktivitas $\beta$ galaktosidase kasar dan hasil dialisis optimum dicapai masing-masing pada $\mathrm{pH} 6.5$ dan suhu $50{ }^{\circ} \mathrm{C}$. Stabilitas $\beta$-galaktosidase kasar yang diikubasi selama 1 jam terjadi pada $\mathrm{pH}$ 5.0-8.5 dan suhu 25$50{ }^{\circ} \mathrm{C}$. Aktivitas spesifik $\beta$-galaktosidase kasar adalah $15.05 \mathrm{U} / \mathrm{mg}$ protein, sedangkan $\beta$ galaktosidase hasil dialisis adalah $109.58 \mathrm{U} / \mathrm{mg}$
\end{abstract}

protein. Hidrolisis laktosa untuk produksi susu $U H T$ rendah laktosa menunjukkan bahwa konsentrasi glukosa meningkat dengan meningkatnya waktu hidrolisis. Waktu yang diperlukan untuk menghidrolisa $50 \%$ laktosa susu UHT dengan 4.8 $\mathrm{U} / \mathrm{mL} \beta$-galakosidase pada suhu $50{ }^{\circ} \mathrm{C}$ adalah 6.08 jam. Disimpulkan bahwa $\beta$-galaktosidase $L$. plantarum B123 indigenos yang dipurifikasi secara parsial dapat digunakan sebagai penghidrolisa laktosa dalam produksi susu $U H T$ rendah laktosa.

Kata kunci: $\beta$-galaktosidase, Lactobacillus plantarum B123 indigenos, purifikasi, hidrolisis laktosa, susu $U H T$

\section{ABSTRACT}

$\beta$-Galactosidase is enzyme which hidrolyze lactose to glucose and galactose. This enzyme is used in production low lactose milk for consumption human which have lactose intolerance. Partial purification of $\beta$-galactosidase is important to be conducted to increase $\beta$-galactosidase activity in order to its hydrolysis potency on UHT milk lactose increased.This research was aimed to production by partially purification and characterization indigenous $\beta$-galactosidase from Lactobacillus plantarum B123, and lactose hydrolysis for production low lactose UHT milk. Partially purification were precipitation following dialysis. Characterization included optimazion and stabilization of enzyme, while lactose hydrolisis for production low lactose UHT milk was detected by enzymatic GOD-POD kit. The results showed that production of $\beta$-galactosidase by using partial purification increased from $21.51 \pm 0.23 \mathrm{U} / \mathrm{mL}$ (crude) to $106.34 \pm 0.56 \mathrm{U} / \mathrm{mL}$ (dialysis). The optimum crude $\beta$-galactosidase activity was 
reached in precipitation by using $60 \%$ ammonium sulphate. The purity of crude $\beta$-galactosidase increased 3.71 times after precipitation, and 14.28 times after dialysis. Characterization of $\beta$ galactosidase showed that optimum activities of crude and dialyzed $\beta$-galactosidase were at $p H 6.5$ and $50{ }^{\circ} \mathrm{C}$, respectively. Stability of crude $\beta$ galactosidase incubated for $1 \mathrm{~h}$ were at $\mathrm{pH}: 5.0-8.5$ and $25-50{ }^{\circ} \mathrm{C}$. Specific activity of crude $\beta$ galactosidase was $15.05 \mathrm{U} / \mathrm{mg}$ protein, while that dialyzed $\beta$-galactosidase was $109.58 \mathrm{U} / \mathrm{mg}$ protein. Lactose hidrolysis to produce low lactose UHT milk showed that glucose concentration increased with the increase of hidrolysis time. Time needed to hidrolyze lactose $50 \%$ with $4.8 \mathrm{U} / \mathrm{mL} \quad \beta$ galactosidase at $50^{\circ} \mathrm{C}$ was $6.08 \mathrm{~h}$. In conclusion that indigenous $\beta$-galactosidase from Lactobacillus plantarum B123 purified partially can be used as lactose hidrolyzer in production of low lactose UHT milk.

Key words: $\quad \beta$-galactosidase, indigenous Lactobacillus plantarum B123, purification, lactose hidrolysis, UHT Milk

\section{PENDAHULUAN}

Enzim yang mempunyai peranan penting dalam menghidrolisa laktosa menjadi glukosa dan galaktosa adalah $\beta$ galaktosidase $\quad(\beta$-D $D$-galactoside galactohydrolase, EC:3.2.1.23) $)^{(1,2)}$. Enzim $\beta$-galaktosidase ini sering dikenal sebagai laktase, dan enzim ini potensial dikembangkan di industri pangan, ${ }^{(3)}$ terutama di industri susu, yaitu untuk produksi susu rendah/bebas laktosa. $^{(4)}$

Berbagai jenis bakteri terutama bakteri asam laktat (BAL) dapat menghasilkan $\beta$-galaktosidase, diantaranya Lb. acidophilus, Lb. plantarum, Streptococus thermophilus, Leuconostoc mesenteroides subsp. cremoris dan Lactococcus lactis. $^{(5)}$ Bakteri asam laktat secara umum termasuk bakteri GRAS (Generally Recognized as Safe), sehingga penggunaan $\beta$-galaktosidase dari BAL dapat digunakan langsung dalam prduk pangan dikarenakan BAL bersifat aman dan tidak toksik. $^{(1,6)}$

Purifikasi parsial $\beta$-galaktosidase penting dilakukan untuk meningkatkan aktivitas $\beta$-galaktosidase agar supaya kegunaannya dalam hidrolisis laktosa susu semakin meningkat ${ }^{(7-10)}$. Produksi $\beta$ galaktosidase dari beberapa bakteri menunjukkan bahwa jenis bakteri penghasil $\beta$-galaktosidase dan jenis purifikasi yang berbeda mempunyai aktivitas $\beta$-galaktosidase yang berbeda ${ }^{(7,11)}$. Enzim $\beta$-galaktosidase kasar yang diekstraksi dari L. bulgarian ssp. (CHR Hansen Lb-12) menghasilkan aktivitas sebesar $20.9 \mathrm{U} / \mathrm{ml},{ }^{(7)}$ sedangkan aktivitas $\beta$ galaktosidase dari Thermotoga maritima hasil purifikasi menggunakan kromatografi gel filtrasi menghasilkan aktivitas sebesar $185 \mathrm{U} / \mathrm{mg}^{(8)}$

Enzim $\quad \beta$-galakosidase dapat dihasilkan oleh BAL ${ }^{.(7,10,11)}$ Lactobacillus plantarum sebagai salah satu BAL penghasil $\quad \beta$-galaktosidase sudah dilaporkan $^{\text {(12) }}$ Karakter $\beta$-galaktosidase $L$. plantarum menunjukkan bahwa $\mathrm{pH}$ optimum $\beta$-galaktosidase dari Lactobacillus plantarum WCFS1 dengan substrat $o$ NPG adalah 7.5 dengan suhu optimum $55^{\circ} \mathrm{C}$. $^{(12)}$ Meskipun demikian, karakter $\beta$ galaktosidase dari L. plantarum B123 indigenos dan hidrolisis laktosa untuk produksi susu UHT rendah laktosa belum diteliti. Proses hidrolisis laktosa dalam produksi susu $U H T$ rendah laktosa penting karena laktosa susu UHT dihidrolisis menjadi glukosa dan galaktosa yang lebih mudah diserap oleh usus manusia untuk konsumsi penderita intoleransi laktosa. Persentase laktosa terhidrolisis bervariasi dan dipengaruhi oleh jenis susu dan mikroba penghasil $\beta$-galaktosidase, konsentrasi $\beta$-galaktosidase, suhu dan waktu hidrolisis. Persentase laktosa terhidrolisis pada susu pasteurisasi oleh $\beta$ galaktosidase Thermotoga maritima dengan konsentrasi $4 \mathrm{U} / \mathrm{mL}$ pada suhu $80{ }^{\circ} \mathrm{C}$ dengan waktu hidrolisis 3 jam adalah 100 $\%,{ }^{(13)}$ sedangkan persentase laktosa terhidrolisis pada susu skim oleh $\beta$-galaktosidase Kluyveromyces lactis, 
GODO-YNL2 (komersial) dengan konsentrasi $60 \mathrm{U} / \mathrm{mL}$ pada suhu $8{ }^{\circ} \mathrm{C}$ dengan waktu hidrolisis 24 jam adalah 99.9 $\% .^{(14)}$ Persentase laktosa terhidrolisis pada susu pasteurisasi oleh $\beta$-galaktosidase $L b$. ssp. bulgaricus (CHR Hansen Lb-12) dengan konsentrasi $0,418 \mathrm{U} / \mathrm{mL}$ pada suhu $52{ }^{\circ} \mathrm{C}$ dengan waktu hidrolisis 6 jam adalah $78 \%,{ }^{(7)}$ sedangkan presentase laktosa terhidrolisis pada susu UHT oleh $\beta$ galaktosidase L. plantarum belum dilaporkan. Penelitian ini difokuskan pada produksi dengan purifikasi parsial dan karakterisasi $\beta$-galaktosidase Lactobacillus plantarum B123 indigenos dan hidrolisis laktosa untuk produksi susu UHT rendah laktosa.

\section{BAHAN DAN METODA BAHAN}

\section{Bahan}

Bahan yang digunakan adalah isolat L. plantarum B123 indigenos dari makanan fermentasi sayuran, merupakan kultur yang diidentifikasi secara molekuler, koleksi Bidang Mikrobiologi, Pusat Penelitian Biologi, LIPI; dan media MRSB (de Mann Rogosa Sharpe Broth). ${ }^{(15)}$

\section{Metode}

\section{Produksi $\beta$-Galaktosidase L. plantarum B123 dengan Purifikasi Parsial}

Produksi $\quad \beta$-galaktosidase $L$. plantarum B123 dilakukan dengan purifikasi parsial, dengan tahap awal adalah ekstraksi enzim, kemudian dilanjutkan pengendapan dengan amonium sulfat dan dialisis menggunakan membran dialisis.

\section{Ekstraksi $\beta$-Galaktosidase $L . \quad$ plantarum} B123 dengan Metoda Wang and Sakakibara $(1997)^{(16)}$

Sebanyak $2 \%$ inokulum $L$. plantarum B123 dengan OD $0.7\left(5.00 \times 10^{7} \mathrm{cfu} / \mathrm{mL}\right)$ diinokulasikan kedalam media produksi yang sudah disterilisasi (MRSB dengan kandungan laktosa $1 \%$ dan $\mathrm{pH}$ medium : 8), dan diinkubasi pada suhu $37{ }^{\circ} \mathrm{C}$. Sel dipanen sesudah waktu inkubasi selama 24 jam. Cairan kemudian disentrifus dengan $9500 \mathrm{rpm}(14330 \times \mathrm{g})$ selama 15 menit pada $4{ }^{\circ} \mathrm{C}$. Pelet dicuci dua kali dengan bufer fosfat $0.05 \mathrm{M} \mathrm{pH}$ 6.5. Pelet yang didapat dilarutkan dalam bufer fosfat 0.05 $\mathrm{M}$ pH 6.5 dan sel dipecah dengan sonikator $50 \mathrm{kHz}$ selama 15 menit pada $4{ }^{\circ} \mathrm{C}$. Suspensi sel kemudian disentrifus dengan kecepatan 9500 rpm selama 15 menit pada suhu $4{ }^{\circ} \mathrm{C}$. Supernatan yang diperoleh merupakan enzim kasar $\beta$-galaktosidase. Aktivitas $\beta$-galaktosidase diukur dengan metoda Lu et al., $2012^{(17)}$ dan konsentrasi protein dideteksi dengan metoda Bradford. $^{(18)}$

Pengendapan Menggunakan Amonium Sulfat dengan Metoda Scopes $(1993)^{(19)}$

Enzim diendapkan untuk determinasi fraksi pengendapan dengan aktivitas spesifik optimum. Enzim $\beta$-galaktosidase kasar ditambahkan amonium sulfat sampai konsentrasi $10 \%$ dengan pengadukan 60 rpm pada suhu $4{ }^{\circ} \mathrm{C}$. Sesudah semua amonium sulfat dilarutkan, pengadukan dilanjutkan selama 20 menit. Campuran kemudian didiamkan selama 1 jam pada 4 ${ }^{\circ} \mathrm{C}$ dan disentrifus dengan $9500 \mathrm{rpm}$ selama 15 menit pada suhu $4{ }^{\circ} \mathrm{C}$. Supernatan yang diperoleh kemudian ditambah kembali amonium sulfat seperti prosedur diatas untuk fraksi pengendapan 20,30, 40, 50, 60 dan $70 \%$. Endapan enzim dipisahkan dan dilarutkan dalam bufer fosfat $0.05 \mathrm{M} \mathrm{pH}$ 6.5 , kemudian disentrifus kembali dengan $9500 \mathrm{rpm}$ selama 15 menit pada $4{ }^{\circ} \mathrm{C}$. Supernatan masing-masing fraksi pengendapan kemudian diukur aktivitas $\beta$ galaktosidase dengan metoda $\mathrm{Lu}$ et al., $2012^{(17)}$ dan konsentrasi protein dengan metoda Bradford. ${ }^{(18)}$ Fraksi pengendapan yang menghasilkan aktivitas spesifik 
optimum adalah $60 \%$, sehingga untuk enzim kasar diendapkan pada konsentrasi $60 \%$.

Jumlah amonium sulfat (dalam gram) yang digunakan untuk melarutkan 1 liter larutan enzim dtunjukkan dalam persamaan (1). S1 adalah konsentrasi awal amonium sulfat, sedangkan S2 adalah konsentrasi akhir amonium sulfat. Nilai 533 adalah jumlah gram amonium sulfat yang diperlukan per liter larutan untuk membuat $100 \%$ larutan jenuh.

Jumlah amonium sulfat $(\mathrm{g} / \mathrm{L})=\frac{533(\mathrm{~S} 2-\mathrm{S} 1)}{100-0.3 \mathrm{~S} 2}$

Dialisis dengan Metoda Jurado et al

Larutan enzim yang dihasilkan dari pengendapan dengan amonium sulfat didialisis menggunakan bufer fosfat $0.01 \mathrm{M}$ pH 6.5 dengan $100 \mathrm{rpm}$. Enzim didialisis pada suhu $4{ }^{\circ} \mathrm{C}$ selama 24 jam dengan membran dialisis selofan. Aktivitas spesifik dan konsentrasi protein $\beta$-galaktosidase hasil dialisis diukur kembali. $\beta$ Galaktosidase hasil dialisis disimpan pada suhu $4{ }^{\circ} \mathrm{C}$.

\section{Aktivitas dan stabilitas $\beta$-galaktosidase}

Aktivitas dan stabilitas $\beta$ galaktosidase L. plantarum B123 dilakukan diberbagai $\mathrm{pH}$ dan suhu. Aktivitas $\beta$ galaktosidase diuji dengan metoda $\mathrm{Lu}$ et al. 2009 yang dimodifikasi, ${ }^{(17)}$ dan stabilitas $\beta$ galaktosidase dilakukan selama penyimpanan 1 jam pada suhu $37{ }^{\circ} \mathrm{C}$.

\section{Aktivitas $\beta$-Galaktosidase dengan Metoda Lu et al. $(2009)^{(17)}$}

Sebanyak $1000 \mu \mathrm{L}$ bufer fosfat $0.1 \mathrm{M}$ pH 7 dan $100 \mu \mathrm{L}$ enzim dituang kedalam tabung reaksi, kemudian diinkubasi pada suhu $37{ }^{\circ} \mathrm{C}$ selama 5 menit. Larutan kemudian ditambahkan $200 \mu \mathrm{L} o \mathrm{NPG} 2$ $\mathrm{mg} / \mathrm{mL}$ dan diinkubasi pada suhu $37{ }^{\circ} \mathrm{C}$ selama 5 menit. Pada menit ke-10 larutan ditambahkan $1000 \mu \mathrm{L} \mathrm{Na} \mathrm{CO}_{3} 1 \mathrm{M}$ untuk menghentikan reaksi. Larutan dianalisa dengan menggunakan spektrofotometer UV Vis pada $\lambda 420 \mathrm{~nm}$.

Kurva standar yang dilakukan di berbagai konsentrasi $o \mathrm{NP}$ dari $0-2.500 \mathrm{mM}$ dilarutkan dalam buffer fosfat $0.01 \mathrm{M} \mathrm{pH} 7$. Sejumlah $1000 \mu \mathrm{L}$ bufer fosfat $0.1 \mathrm{M} \mathrm{pH} 7$ dan $100 \mu \mathrm{L}$ aquades dituang kedalam tabung reaksi, kemudian ditambahkan 200 $\mu \mathrm{L} o \mathrm{NP}$ diberbagai konsentrasi. Larutan diinkubasi pada suhu $35^{\circ} \mathrm{C}$ selama 5 menit. Kemudian, larutan ditambahkan $1000 \mu \mathrm{L}$ $\mathrm{Na}_{2} \mathrm{CO}_{3} 1$ M. Larutan di-vortex dan intensitas warna kuning diukur absorbannya pada $\lambda 420 \mathrm{~nm}$. Aktivitas $\beta$-galaktosidase diplot dengan hasil kurve standar. Satu unit aktivitas $\beta$-galaktosidase didefinisikan sebagai jumlah enzim yang diperlukan untuk menghasilkan $1 \mu \mathrm{mol} o \mathrm{NP}$ dari subsrat $o$ NPG per menit pada kondisi perlakuan. Aktivitas spesifik $\beta$ galaktosidase diplot dengan hasil kurva standar protein. Kurva standar protein dibuat dengan bovine serum albumin $(B S A)$, dengan berbagai konsentrasi dari $0.00-0.60 \mathrm{mg} / \mathrm{mL}$. Sejumlah $20 \mu \mathrm{L} \beta-$ galaktosidase ditambah $1 \mathrm{~mL}$ reagen Bradford. $^{(18)}$ Larutan di vortex dan didiamkan selama 5 menit, kemudian diukur absorbannya pada $\lambda 595 \mathrm{~nm}$.

\section{Aktivitas $\beta$-Galaktosidase pada Berbagai pH dan Suhu}

Aktivitas $\beta$-galaktosidase di-berbagai $\mathrm{pH}$ diukur dengan cara: sejumlah $100 \mu \mathrm{L}$ enzim kasar dituang kedalam $1 \mathrm{~mL}$ bufer $0.1 \mathrm{M}$ dengan variasi $\mathrm{pH}$ antara $\mathrm{pH}$ 4.5-8.5 ( $\mathrm{pH}$ interval : 0.5), sedangkan aktivitas diberbagai suhu diukur dengan cara: sejumlah $100 \mu \mathrm{L}$ enzim kasar dituang kedalam $1 \mathrm{~mL}$ bufer $0.1 \mathrm{M}$ pH optimum, kemudian diinkubasi selama 5 menit pada masingmasing suhu $\left(25-60{ }^{\circ} \mathrm{C}\right.$ dengan interval: 5 $\left.{ }^{\circ} \mathrm{C}\right)$. Kemudian aktivitas $\beta$-galaktosidase 
diukur dengan metoda $\mathrm{Lu}$ et al., 2012. ${ }^{17}$ Aktivitas enzim kemudian didefinisikan sebagai aktivitas relatif (\%), yaitu aktivitas pada $\mathrm{pH}$ atau suhu tertentu $(\mathrm{U} / \mathrm{mL})$ dibagi aktivitas tertinggi (U/mL) x $100 \%$. Masing-masing nilai $\mathrm{pH}$ dan suhu yang memberikan aktivitas relatif tertinggi menunjukkan masing-masing $\mathrm{pH}$ dan suhu optimum $\beta$-galaktosidase.

\section{Stabilitas $\beta$-Galaktosidase Diberbagai $p H$ dan Suhu}

Stabilitas $\beta$-galaktosidase di berbagai $\mathrm{pH}$ diuji dengan cara: sejumlah $50 \mu \mathrm{L}$ enzim kasar dituang kedalam $50 \mu \mathrm{L}$ bufer $0.1 \mathrm{M}$ dengan $\mathrm{pH}$ 4.5-8.5 (interval $\mathrm{pH}$ : 0.5). Campuran enzim dan bufer kemudian disimpan pada suhu $37^{\circ} \mathrm{C}$ selama 1 jam, kemudian didinginkan dan ditambah $1 \mathrm{~mL}$ bufer $0.1 \mathrm{M}$ pada $\mathrm{pH}$ optimum. Stabilitas $\beta$ galaktosidase diberbagai suhu diuji dengan cara: sejumlah $100 \mu \mathrm{L}$ enzim kasar dituang kedalam $1 \mathrm{~mL}$ bufer $0.1 \mathrm{M}$ pada $\mathrm{pH}$ optimum. Campuran enzim dan bufer kemudian disimpan selama 1 jam pada berbagai suhu $\left(25-60^{\circ} \mathrm{C}\right.$ dengan interval: $\left.5^{\circ} \mathrm{C}\right)$ dan didinginkan. Aktivitas $\beta$ galaktosidase kemudian diukur dengan metoda Lu et al., 2009, ${ }^{(17)}$ dengan inkubasi pada suhu optimum.

\section{Laktosa susu UHT yang tidak Terhidrolisa}

Laktosa susu UHT yang tidak terhidrolisa dideteksi dengan menggunakan kit enzimatik GOD-POD. Tahapan deteksi ini meliputi hidrolisis laktosa susu $U H T$, analisa laktosa susu $U H T$ dan penghitungan jumlah laktosa susu $U H T$ yang tidak terhidrolisis

\section{Hidrolisis Laktosa Susu UHT}

Sejumlah $4.8 \mathrm{U} / \mathrm{mL} \quad \beta$-galaktosidase hasil dialisis dituang kedalam susu UHT. Sampel diinkubasi pada suhu dan waktu inkubasi optimum. Kontrol adalah susu UHT tanpa penambahan $\beta$-galaktosidase atau didefinisikan sebagai perlakuan jam ke-0. Setiap jam (jam ke-0 sehingga jam ke-12) sejumlah $250 \mu \mathrm{L}$ sampel diambil, kemudian dianalisa glukosa dengan kit enzimatik GOD-POD

\section{Analisa Laktosa Susu UHT}

Sebanyak $1 \mathrm{~mL}$ reagen GOD-POD diperlakukan pemanasan awal selama 5 menit pada $37{ }^{\circ} \mathrm{C}$. Sejumlah $10 \mu \mathrm{L}$ sampel susu UHT (kontrol dan perlakuan $\beta$ galaktosidase) ditambahkan kedalam reagen GOD-POD dan diinkubasi selama 10 menit pada suhu $37{ }^{\circ} \mathrm{C}$. Larutan dianalisa dengan spektrofotometer UV-Vis pada $\lambda 505 \mathrm{~nm}$. Absorban yang didapatkan dibandingkan dengan absorban standar glukosa 100 $\mathrm{mg} / \mathrm{dL}$. Jumlah glukosa yang terbentuk pada kondisi perlakuan didefinisikan dalam mg/dL kemudian diubah ke \% (b/v).

Jumlah Laktosa Susu UHT yang Tidak Terhidrolisa dengan Metoda Kishore and Kayastha $(2012)^{(20)}$

Jumlah laktosa yang tidak terhidrolisa dihitung berdasarkan jumlah glukosa tanpa perlakuan enzim dibagi jumlah glukosa dengan perlakuan enzim dikalikan $100 \%$

Korelasi grafik antara log \% laktosa yang tidak terhidrolisa (y axis) dan waktu ( $\mathrm{x}$ axis).

$$
\begin{aligned}
& \text { Kecepatan reaksi }(\mathrm{k})=\frac{2.303}{\mathrm{t}} \log \frac{100}{100-\mathrm{x}} \\
& \begin{array}{r}
x=\text { laktosa yang tidak terhidrolisis } \\
\mathrm{t}_{1 / 2}=0.693 / \mathrm{k}
\end{array} \\
& \begin{array}{l}
t_{1 / 2}=\text { waktu yang diperlukan untuk menghidrolisa 50\% laktosa } \\
k=\text { konstanta kecepatan reaksi }
\end{array}
\end{aligned}
$$




\section{Data Analisa}

Data hasil penelitian dianalisa secara statistik menggunakan analysis of variance (ANOVA). Jika hasil analisa statistik didapatkan pengaruh yang signifikan ( $p<0.05$ ), pengujian dilanjutkan dengan uji Duncan. Software yang digunakan adalah IBM SPSS Statistics 20.

\section{HASIL DAN PEMBAHASAN}

Produksi $\beta$-galaktosidase kasar dari bakteri L. plantarum B123 indigenos lebih tinggi dibandingkan dari L. bulgarian ssp. (CHR Hansen Lb-12). Hal ini ditunjukkan dengan aktivitas $\beta$-galaktosidase kasar dari L. plantarum B123 indigenos yang lebih tinggi (Tabel 1) dari aktivitas $\beta$ galaktosidase kasar dari L. bulgarian ssp. (CHR Hansen Lb-12). ${ }^{(7)}$ Enzim $\beta$ galaktosidase dari $L$. plantarum B123 mempunyai kisaran suhu dan $\mathrm{pH}$ yang luas sehingga enzim ini dapat digunakan untuk aplikasi biokonverter laktosa untuk produk susu (Gambar 4-5). Enzim $\beta$-galakosidase L. plantarum $\mathrm{B} 123$ hasil dialisis sebesar 4.8 $\mathrm{U} / \mathrm{mL}$ berpotensi menghidrolisa $50 \%$ laktosa susu $U H T$ pada suhu $50^{\circ} \mathrm{C}$ selama 6.08 jam (Gambar 6-7).

\section{Produksi $\beta$-galaktosidase Lactobacillus plantarum B123 dengan purifikasi parsial.}

Purifikasi parsial $\beta$-galaktosidase dari L. plantarum B123 menghasilkan peningkatan aktivitas spesifik $\beta$ galaktosidase dari $15.05 \mathrm{U} / \mathrm{mg}$ enzim kasar menjadi $55.88 \mathrm{U} / \mathrm{mg}$ enzim hasil pengendapan dengan menggunakan amonium sulfat $60 \%$, dan selanjutnya meningkat menjadi $109.58 \mathrm{U} / \mathrm{mg}$ enzim hasil dialisis (Tabel 1). $\beta$-Galaktosidase kasar meningkat purifikasinya sebesar 3,71 kali setelah enzim diendapkan dengan amonium sulfat $60 \%$, dan meningkat lagi sebesar 7,28 kali setelah enzim didialisis (Tabel 1). Hasil penelitian menunjukkan bahwa dengan purifikasi parsial, aktivitas spesifik $\beta$-galaktosidase $L$. plantarum $\mathrm{B} 123$ mengalami peningkatan.

Enzim $\beta$-galaktosidase $L$. plantarum B123 yang dipurifikasi parsial diproduksi melalui beberapa tahapan mulai dari ekstraksi enzim untuk menghasilkan enzim kasar, pengendapan dengan amonium sulfat, dan dialisis. Enzim $\beta$-galactosidase L. plantarum B123 adalah enzim intraselluler, sehingga dalam proses produksi diperlukan sonikasi untuk pemecahan dinding sel. Pengendapan terjadi karena kompetisi antara garam dan protein untuk pengikatan air ${ }^{(21)}$. Faktorfaktor yang dapat mempengaruhi dialisis adalah pelarut, suhu, tekanan atau perubahan yang terjadi dalam membran. ${ }^{(22)}$ Ukuran mebran dialisis selofan yang digunakan adalah 6-8 $\mathrm{kDa}$ MWCO, sehingga molekul-molekul lain yang mempunyai ukuran kurang dari 6-8 $\mathrm{kDa}$ keluar dari membran semi-permeabel. Enzim $\beta$-galaktosidase dari beberapa strains Lactobacillus mempunyai BM: $116 \mathrm{kDa}{ }^{(23)}$ Enzim $\beta$-galaktosidase dari L. plantarum membentuk mono dan dimer dengan perkiraan BM: 107 dan 214 kDa. ${ }^{(24)}$

Tabel 1. Total protein, aktivitas dan yield $\beta$-galaktosidase dari Lb. plantarum B123 indigenos

\begin{tabular}{lcccccc}
\hline \multicolumn{1}{c}{ Tahapan } & $\begin{array}{c}\text { Total protein } \\
(\mathbf{m g})\end{array}$ & $\begin{array}{c}\text { Aktivitas } \\
(\mathbf{U})\end{array}$ & $\begin{array}{c}\text { Aktivitas } \\
(\mathbf{U} / \mathbf{m L})\end{array}$ & $\begin{array}{c}\text { Aktivitas } \\
\text { spesifik } \\
(\mathbf{U} / \mathbf{m g})\end{array}$ & $\begin{array}{c}\text { Purifikasi } \\
(\mathbf{f o l d})\end{array}$ & $\begin{array}{c}\text { Yield } \\
(\boldsymbol{\%})\end{array}$ \\
\hline $\begin{array}{l}\text { Enzim kasar } \\
\text { (crude enzyme) }\end{array}$ & $171.45 \pm 7.36$ & $2581.18 \pm 27.86$ & $21.51 \pm 0.23$ & 15.05 & 1 & 100 \\
$\begin{array}{l}\text { Pengendapan dengan } \\
\text { amonium sulfat 60\% }\end{array}$ & $15.56 \pm 2.15$ & $869.3 \pm 17.44$ & $173.86 \pm 3.49$ & 55.88 & 3.71 & 33.68 \\
Dialisis & $3.30 \pm 0.24$ & $361.54 \pm 1.92$ & $106.34 \pm 0.56$ & 109.58 & 7.28 & 14.01 \\
\hline
\end{tabular}

Nilai dinyatakan sebagai rata-rata \pm standar deviasi dari 3 ulangan 
Hasil pengendapan dengan amonium sulfat menunjukkan bahwa aktivitas optimum $(173.86 \pm 3.49 \mathrm{U} / \mathrm{mL})$ dan aktivitas spesifik optimum $(55.88 \mathrm{U} / \mathrm{mg}$ protein) dihasilkan pada konsentrasi amonium sulfat $60 \%$ (Gambar 1). Secara statistik, konsentrasi amonium sulfat berpengaruh nyata terhadap aktivitas dan

Hasil pengendapan dengan amonium sulfat menunjukkan bahwa aktivitas optimum $(173.86 \pm 3.49 \mathrm{U} / \mathrm{mL})$ dan aktivitas spesifik optimum $(55.88 \mathrm{U} / \mathrm{mg}$ protein) dihasilkan pada konsentrasi amonium sulfat $60 \%$ (Gambar 1). Secara statistik, konsentrasi amonium sulfat berpengaruh nyata terhadap aktivitas dan aktivitas spesifik $\beta$-galaktosidase $(\mathrm{p}<0.05)$. Akibatnya, pengendapan amonium sufat yang digunakan adalah pada konsentrasi 60 $\%$

Gambar 1. menunjukkan bahwa konsentrasi amonium sulfat berpengaruh terhadap aktivitas dan aktivitas spesifik $\beta$ galaktosidase L. plantarum B123. Semakin meningkat konsentrasi amonium sulfat yang ditambahkan, semakin meningkat aktivitas dan aktivitas spesifik enzim dan aktivitas optimum tercapai pada konsentrasi amonium sulfat $60 \%$. Hal ini disebabkan karena semakin meningkat konsentrasi amonium sulfat yang ditambahkan, semakin meningkat kelarutan protein, dan sampai pada konsentrasi tertentu kelarutan protein menurun. Konsentrasi amonium sulfat yang optimum ini sekaligus menurunkan aktivitas enzim, karena sebagian protein mengalami denaturasi dan rusak selama pengendapan. ${ }^{(19)}$

Yield yang dihasilkan setelah dialisis sebesar $14.01 \%$ menunjukkan bahwa dialisis pada $\beta$ - galaktosidase dari $L b$. plantarum B123 indigenos kasar adalah efektif dan efisien (Tabel 1). Hal ini dikarenakan kemurnian $\beta$-galaktosidase meningkat dari 1 fold ( $\beta$-galaktosidase kasar) menjadi 7.28 fold ( $\beta$-galaktosidase hasil dialisis).
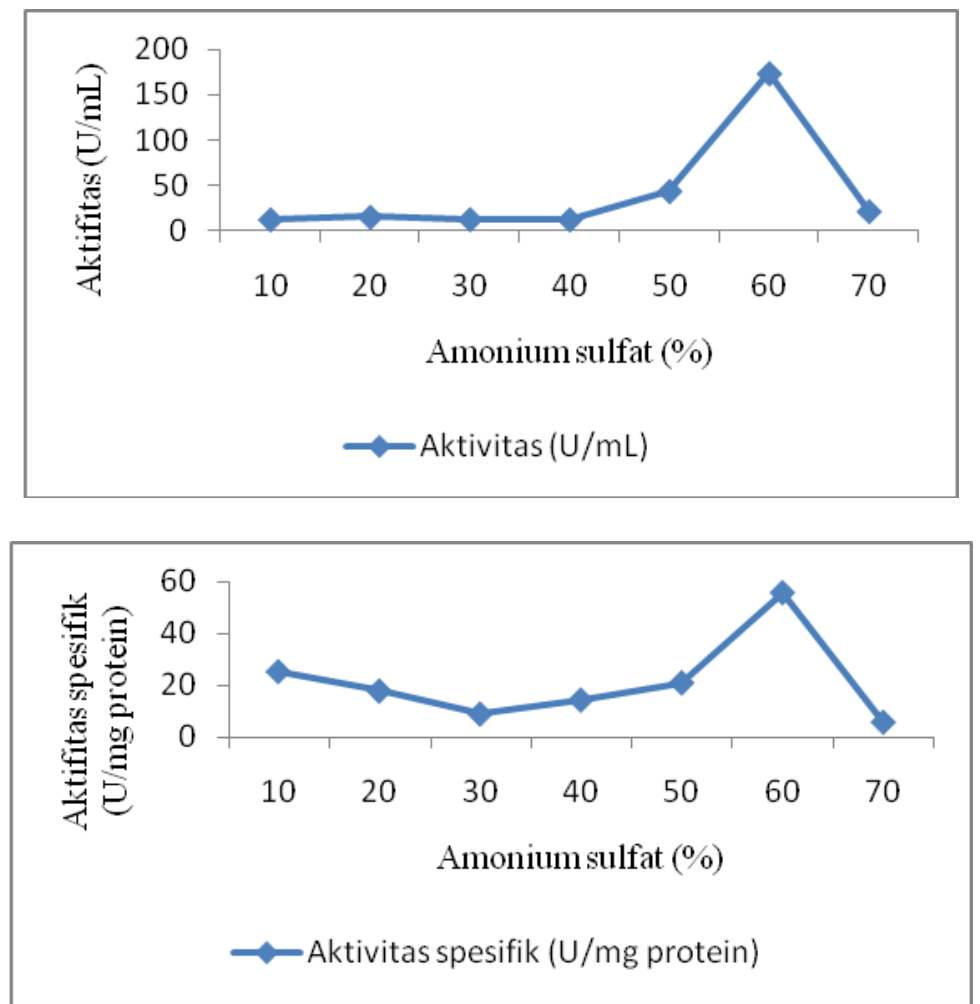

Gambar 1. Aktivitas (a) dan aktivitas spesifik (b) $\beta$-galaktosidase kasar dari Lb. plantarum B123 indigenos diberbagai konsentrasi amonium sulfat 
Selain itu dari Tabel 1 menunjukkan bahwa aktivitas spesifik $\beta$-galaktosidase meningkat dari $15,05 \quad \mathrm{U} / \mathrm{mg} \quad(\beta-$ galaktosidase kasar) menjadi 109,58 U/mg ( $\beta$-galaktosidase hasil dialisis).

Produksi $\beta$-galaktosidase dari beberapa mikroorganisme menunjukkan bahwa perbedaan jenis mikroorganisme penghasil $\beta$-galaktosidase dan jenis purifikasi mempengaruhi aktivitas dan aktivitas spesifik $\beta$-galaktosidase. Purifikasi lebih lanjut, menggunakan kromatografi gel filtrasi menghasilkan aktivitas lebih tinggi, seperti $\beta$-galaktosidase yang dihasilkan dari

Thermotoga maritima yang menghasilkan aktivitas sebesar $185 \mathrm{U} / \mathrm{mg} .{ }^{(8)}$ Enzim $\beta$-galaktosidase kasar yang diekstraksi dari L. bulgarian ssp. (CHR Hansen Lb-12) menghasilkan aktivitas sebesar $20.9 \mathrm{U} / \mathrm{ml} .{ }^{(7)}$ Hasil ini menunjukkan bahwa aktivitas $\beta$-galaktosidase kasar dari L. bulgarian ssp. (CHR Hansen Lb-12) lebih rendah dibandingkan aktivitas $\beta$ galaktosidase yang dihasilkan dari $L$. plantarum B123 indigenos yang mempunyai aktivitas sebesar 21.51 \pm 0.23 $\mathrm{U} / \mathrm{mL}$ atau $15.05 \mathrm{U} / \mathrm{mg}$ (enzim kasar) dan $109.58 \mathrm{U} / \mathrm{mg}$ protein (enzim hasil dialisis), dimana purifikasi dilakukan hanya sampai pada tahapan dialisis. Aktivitas $\beta$ galaktosidase kasar dari L. plantarum B123 indigenos $(21.51 \pm 0.23 \mathrm{U} / \mathrm{mL})$ yang lebih tinggi dari aktivitas $\beta$-galaktosidase kasar dari L. bulgarian ssp. (CHR Hansen Lb-12) (20.9 U/mL) menunjukkan bahwa $L$. plantarum B123 indigenos merupakan bakteri asam laktat lokal penghasil $\beta$ galaktosidase yang produksi enzim kasarnya $(\mathrm{U} / \mathrm{mL})$ lebih tinggi dibandingkan dari L. bulgarian ssp. (CHR Hansen Lb12).

\section{Karakteristik $\quad$-galaktosidase L. plantarum B123}

Karakteristik $\beta$-galaktosidase $L$. plantarum B123 yang dideteksi meliputi optimasi $\mathrm{pH}$ dan suhu $\beta$-galaktosidase kasar dan hasil dialisis, beserta stabilitas $\mathrm{pH}$ dan suhu $\beta$-galaktosidase kasar.

Optimasi $\mathrm{pH}$ dilakukan dengan mendeteksi aktivitas relatif $\beta$-galaktosidase masing-masing diberbagai $\mathrm{pH}$ antara $\mathrm{pH}$ 4,5-8,5, dan aktivitas optimum $\beta$ galaktosidase terjadi pada $\mathrm{pH}$ dengan aktivitas relatif tertinggi. Aktivitas $\beta$ galaktosidase diberbagai $\mathrm{pH}$ (Gambar 2) menunjukkan bahwa $\mathrm{pH}$ optimum $\beta$ galaktosidase enzim kasar dan hasil dialisis dari L. plantarum B123 dalam menghidrolisa substrat oNPG adalah 6.5. Secara statistik, nilai $\mathrm{pH}$ berpengaruh nyata terhadap aktivitas $\beta$-galaktosidase $(p<0.05)$. Nilai $\mathrm{pH}$ optimum $\beta$-galaktosidase dari $L$. plantarum WCFS1 dengan substrat $o$ NPG adalah $7.5,{ }^{(12)}$ sedangkan $\mathrm{pH}$ optimum $\beta$ galaktosidase $L$. plantarum adalah $6,8 .^{(24)}$ Hal ini menunjukkan bahwa perbedaan jenis bakteri mengakibatkan perbedaan $\mathrm{pH}$ optimum $\quad \beta$-galaktosidase yang dihasilkannya. Dilaporkan bahwa karkteristik $\beta$-galaktosidase dari jenis bakteri yang berbeda berpengaruh terhadap interaksinya dengan molekul substrat yang mengakibatkan terjadinya perbedaan $\mathrm{pH}$ optimum enzim yang dihasilkannya. ${ }^{(12,24)}$

Gambar 2 menunjukkan $\beta$ galaktosidase L. plantarum B123 mempunyai aktivitas tertinggi pada $\mathrm{pH} 6.5$ dengan aktivitas relatif sebesar 97,38\%. Selanjutnya aktivitas $\beta$-galaktosidase menurun seiring dengan peningkatan $\mathrm{pH}$. Menurunnya aktivitas enzim karena perubahan $\mathrm{pH}$ larutan yang tidak terlalu besar (sedikit dibawah atau diatas $\mathrm{pH}$ optimalnya) disebabkan oleh berubahnya keadaan ion enzim dan seringkali juga keadaan ion substrat. Pada $\mathrm{pH}$ tertentu terjadi denaturasi enzim yang mengakibatkan turunnya aktivitas enzim secara bertahap. ${ }^{(25)}$ 


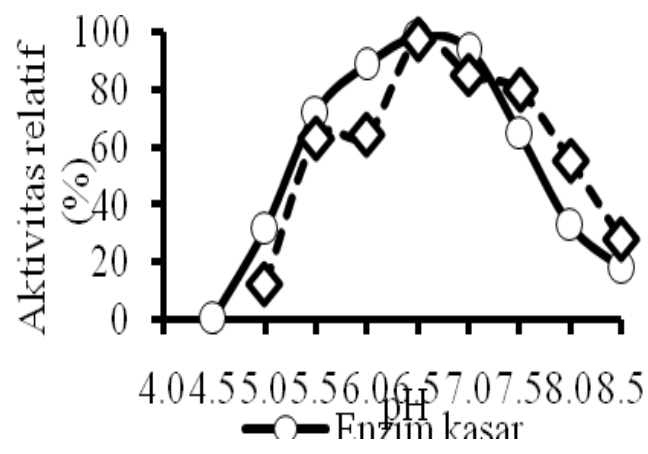

Gambar 2. Aktivitas relatif $\beta$-galaktosidase dari Lb. splantarum B123 indigenos pada berbagai $\mathrm{pH}$

Aktivitas $\beta$-galaktosidase diberbagai suhu (Gambar 3) menunjukkan bahwa suhu optimum $\beta$-galaktosidase enzim kasar dan hasil dialisis dari L. plantarum B123 dalam menghidrolisa substrat $o$ NPG adalah $50{ }^{\circ} \mathrm{C}$. Secara statistik, nilai suhu berpengaruh nyata terhadap aktivitas $\beta$ galaktosidase $(\mathrm{p}<0.05)$. Nilai suhu optimum $\beta$-galaktosidase dari L. plantarum WCFS1 dengan substrat $o \mathrm{NPG}$ adalah $55{ }^{\circ} \mathrm{C},{ }^{(12)}$ sedangkan suhu optimum $\beta$-galaktosidase L. plantarum $56{ }^{\circ} \mathrm{C}^{(24)}$. Hal ini menunjukkan bahwa perbedaan jenis bakteri mengakibatkan perbedaan suhu optimum $\quad \beta$-galaktosidase yang dihasilkannya. Dilaporkan bahwa karkteristik $\beta$-galaktosidase dari jenis bakteri yang berbeda berpengaruh terhadap interaksinya dengan molekul substrat yang mengakibatkan terjadinya perbedaan suhu optimum enzim yang dihasilkannya. ${ }^{(12,24)}$

Gambar 3 menunjukan aktivitas relatif $\beta$-galaktosidase $L$. plantarum $\mathrm{B} 123$ meningkat hingga suhu $50^{\circ} \mathrm{C}$. Enzim $\beta$ galaktosidase pada suhu $50^{\circ} \mathrm{C}$ menunjukkan aktivitas relatif tertinggi dengan nilai 94,42 $\%$, dan aktivitasnya akan menurun pada suhu $55{ }^{\circ} \mathrm{C}$. Sebelum suhu optimum, aktivitas enzim meningkat karena terjadi peningkatan energi kinetik yang mempercepat gerak vibrasi, translasi, serta rotasi enzim dan substrat sehingga memperbesar peluang keduanya untuk saling bertumbukan. Suhu yang lebih besar dari suhu optimum menyebabkan protein enzim mengalami perubahan konformasi yang menyebabkan aktivitasnya berkurang. Substrat juga dapat mengalami perubahan konformasi sehingga sisi reaktifnya tidak dapat lagi atau mengalami hambatan dalam memasuki sisi aktif enzim pada suhu tinggi. $(25,26)$

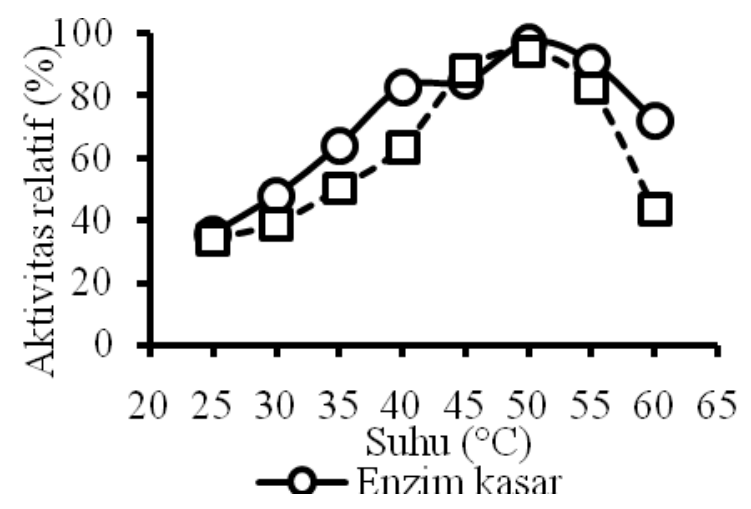

Gambar 3. Aktivitas relatif $\beta$-galaktosidase dari Lb. splantarum $\mathrm{B} 123$ indigenos pada berbagai suhu

Stabilitas $\quad \beta$-galaktosidase $\quad L$. plantarum B123 dilakukan dengan inkubasi enzim selama 1 jam diberbagai $\mathrm{pH}$ dan suhu, kemudian direaksikan dengan substrat $o$ NPG untuk menghasilkan berbagai aktivitas enzim. Kestabilan enzim berhubungan dengan ketahanan enzim dalam mempertahankan konformasinya terhadap kondisi lingkungan sehingga tidak mengubah kedudukan sisi aktif. ${ }^{(26)}$

Stabilitas enzim kasar $\beta$-galaktosidase dari L. plantarum B123 yang diinkubasi selama 1 jam terjadi pada $\mathrm{pH}$ : 5.0-8.5 (Gambar 4). Nilai $\mathrm{pH}$ berpengaruh nyata terhadap aktivitas enzim $(\mathrm{p}<0.05)$. Gambar 4 menunjukan pengaruh $\mathrm{pH}$ terhadap aktivitas relatif $\beta$-galaktosidase $L$. plantarum B123. Enzim $\beta$-galaktosidase relatif stabil setelah diinkubasikan selama 1 jam pada kisaran $\mathrm{pH}$ 5,5-8,5 karena masih menyisakan aktivitasnya diatas $50 \%$. Sebagai perbandingan, stabilitas $\beta$ galaktosidase dari L.plantarum WCFS1 terjadi pada $\mathrm{pH}$ 6.5-8.0. ${ }^{(12)}$ Enzim $\beta$ galaktosidase dari Streptococcus themophilus LMD9 stabil pada kisaran $\mathrm{pH}$ $6,5-7,5,{ }^{(27)}$ dan Kluyveromyces lactis 


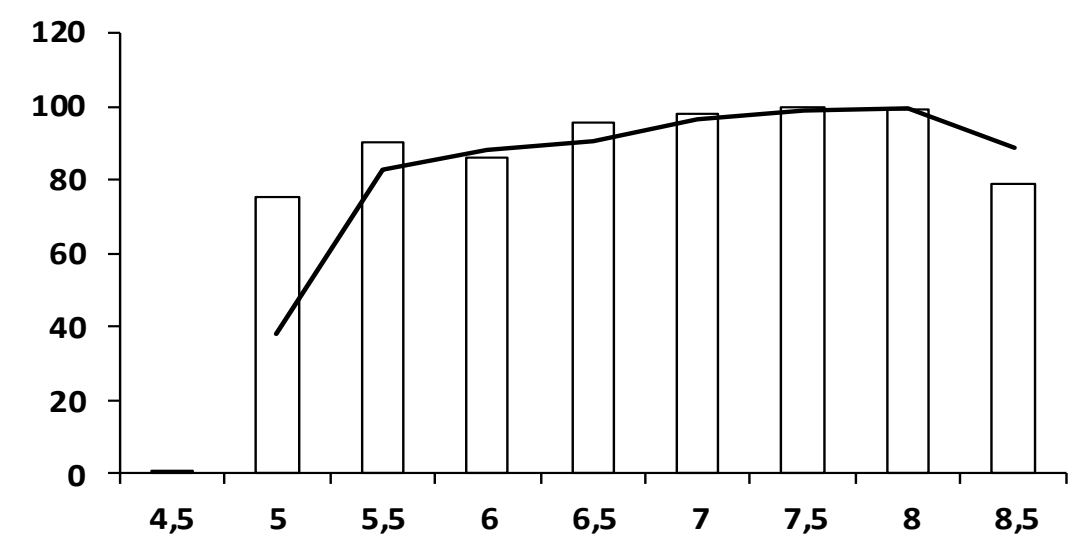

Gambar 4. Aktivitas relatif (\%) $\beta$-galaktosidase kasar dari L. plantarum B123 indigenos yang diinkubasi selama 1 jam pada berbagai $\mathrm{pH}$

berkisar pada $\mathrm{pH} 7,0 .^{(28)}$ Szczodiak $^{(29)}$ menyatakan $\beta$-galaktosidase yang dapat digunakan untuk biokonverter laktosa pada susu harus dapat aktif pada $\mathrm{pH}$ 6,7-6,8 dan biokonverter pada whey dapat aktif pada $\mathrm{pH}$ 5,5-6,0. Berdasarkan penelitian ini, $\beta$ galaktosidase dari L. plantarum B123 mempunyai kisaran $\mathrm{pH}$ yang luas sehingga enzim ini dapat digunakan untuk aplikasi biokonverter laktosa untuk produk susu.
Stabilitas $\quad \beta$-galaktosidase $L$. plantarum B123 juga dilakukan dengan inkubasi enzim selama 1 jam diberbagai suhu, kemudian direaksikan dengan substrat $o$ NPG untuk menghasilkan berbagai aktivitas enzim. Stabilitas enzim kasar $\beta$ galaktosidase dari L. plantarum B123 yang diinkubasi selama 1 jam terjadi pada suhu: $25-50^{\circ} \mathrm{C}$ (Gambar 5). Nilai suhu inkubasi berpengaruh nyata terhadap aktivitas enzim $(\mathrm{p}<0.05)$.

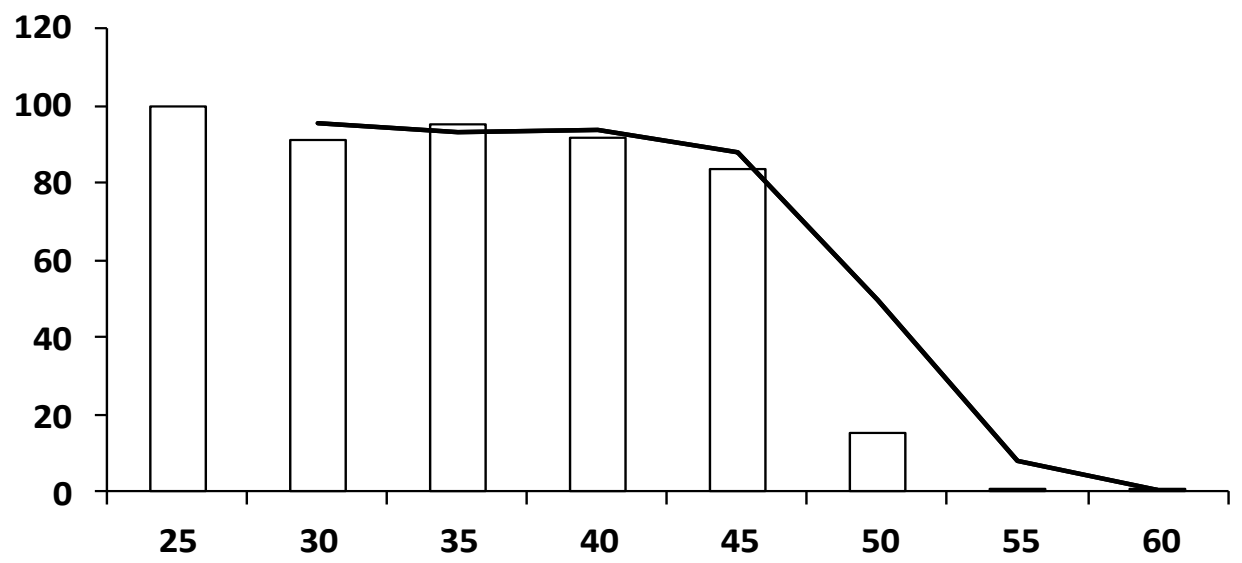

Gambar 5. Aktivitas relatif (\%) $\beta$-galaktosidase kasar dari L. plantarum B123 indigenos yang diinkubasi selama 1 jam pada berbagai suhu 
Kestabilan enzim terhadap panas dapat terjadi karena pelipatan asam amino penyusun protein membentuk konformasi tertentu yang tahan terhadap efek denaturasi akibat panas. Gambar 5 menunjukan pengaruh suhu terhadap aktivitas relatif $\beta$ galaktosidase L. plantarum B123. Enzim $\beta$ galaktosidase relatif stabil setelah diinkubasikan selama 1 jam pada kisaran suhu $25-45{ }^{\circ} \mathrm{C}$ karena masih menyisakan aktivitasnya diatas $50 \%$. Peningkatan suhu meningkatkan kecepatan reaksi sampai batas optimum. Hal ini disebabkan pada kisaran suhu tersebut aktivitas $\beta$ galaktosidase masih dapat menyisakan aktivitasnya diatas $50 \%$. Selanjutnya mengalami penurunan pada suhu $50{ }^{\circ} \mathrm{C}$ dengan menyisakan 15,22 \% dari aktivitasnya. Penurunan aktivitas pada enzim pada suhu $50{ }^{\circ} \mathrm{C}$ terlalu signifikan karena protein enzim terdenaturasi akibat peningkatan suhu. ${ }^{(30)} \quad$ Sebagai perbandingan, suhu optimum $\beta$ galaktosidase E. cloacae B5 sekitar $35{ }^{\circ} \mathrm{C}$ dan enzim ini stabil pada suhu dibawah 30 ${ }^{\circ} \mathrm{C}$. ${ }^{(31)}$ Berdasarkan penelitian ini, $\beta$ galaktosidase dari L. plantarum B123 mempunyai kisaran suhu yang luas sehingga enzim ini dapat digunakan untuk aplikasi biokonverter laktosa untuk produk susu.

Penambahan substrat $o$ NPG dalam uji stabilitas dilakukan pada enzim kasar $\beta$ galaktosidase dan diinkubasi selama 1 jam diberbagai $\mathrm{pH}$ dan suhu. $\beta$-Galaktosidase adalah enzim yang mempunyai karakteristik induktif, aktivitasnya bergantung substrat pada awal reaksi, sehingga hal ini menyebabkan penurunan aktivitas pada suhu: $50{ }^{\circ} \mathrm{C}$ (Gambar 5). Kecepatan reaksi yang dikatalisis enzim sangat dipengaruhi oleh berbagai konsentrasi substrat terhadap kecepatan reaksi awal apabila konsentrasi enzim dijaga konstan. Konsentrasi substrat yang amat rendah menyebabkan kecepatan reaksi amat rendah tetapi kecepatan akan meningkat dengan meningkatnya konsentrasi substrat. Pada akhirnya, akan tercapai titik batas, dan setelah titik ini dilampaui, kecepatan reaksi hanya akan meningkat sedemikian kecil dengan bertambahnya konsentrasi substrat. Pada batas ini, enzim menjadi jenuh oleh substratnya dan tidak dapat berfungsi lebih cepat. $^{26}$

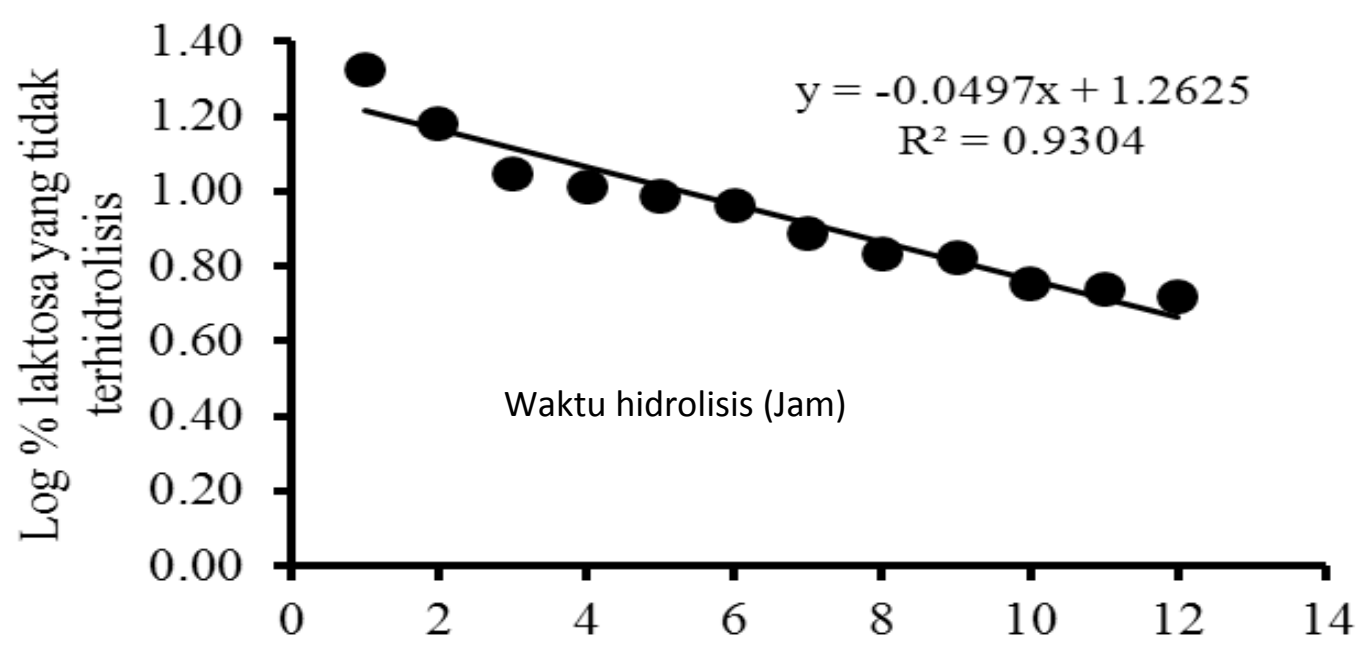

Gambar 6. Log \% laktosa yang tidak terhidrolisis susu UHT dengan penambahan $\beta$-galaktosidase diberbagai waktu hidrolisis 


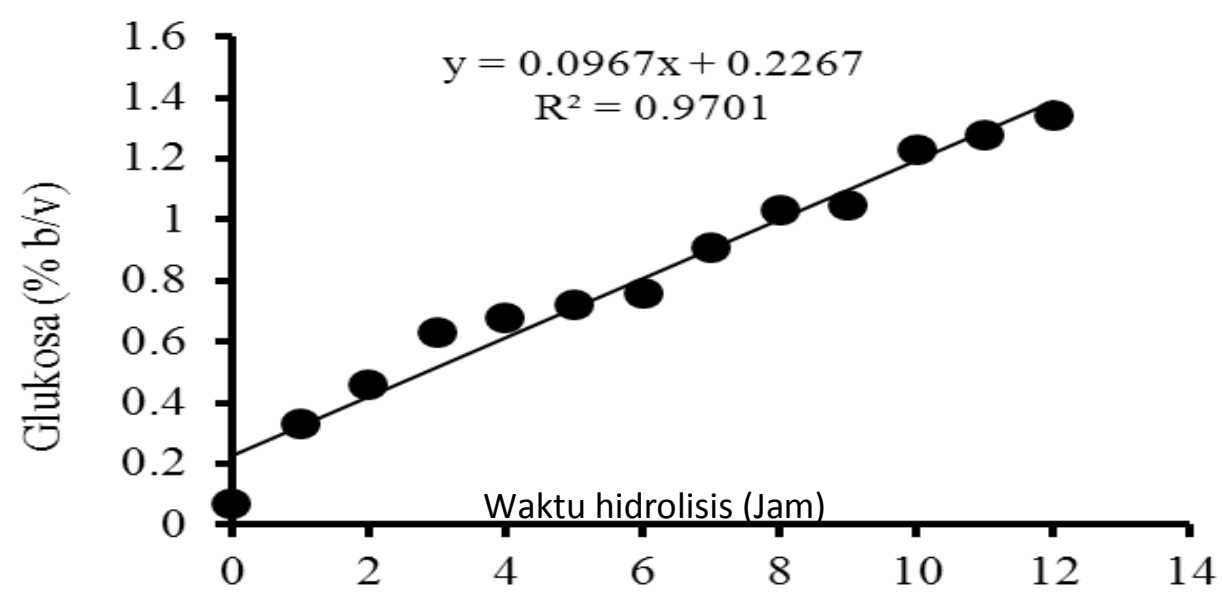

Gambar 7. Kandungan glukosa susu $U H T$ dengan penambahan $\beta$-galaktosidase diberbagai waktu hidrolisis

Hidrolisis laktosa pada susu UHT dengan kit enzimatik GOD-POD

Hasil penelitian menunjukkan bahwa jumlah laktosa yang tidak terhidrolisis menurun (Gambar 6). Gambar 6 menunjukkan persamaan garis linier dengan nilai $\mathrm{R}^{2}=0.9304$, slope dengan nilai negatif menunjukkan adanya penurunan laktosa yang tidak terhidrolisa selama waktu hidrolisis (jam). Dari persamaan garis ini didapatkan $\mathrm{k}$ (konstanta kecepatan reaksi hidrolisis) sebesar 0.114 /jam, dan $t_{1 / 2}$ (prediksi waktu yang diperlukan untuk menghidrolisa $50 \%$ laktosa dalam susu UHT dengan penambahan $4.8 \mathrm{U} / \mathrm{mL}$ konsentrasi enzim pada suhu $50{ }^{\circ} \mathrm{C}$ ) adalah 6.08 jam.

Gambar 7 menunjukkan semakin tinggi waktu hidrolisis, semakin tinggi konsentrasi glukosa dengan persamaan garis linier $\left(\mathrm{R}^{2}=0.9701\right)$. Slope dengan nilai positif menunjukkan peningkatan glukosa selama waktu hidrolisis (jam). Hal ini menunjukkan bahwa $\beta$-galaktosidase $L$. plantarum B123 dapat menghidrolisa laktosa pada susu $U H T$ menjadi glukosa dan galaktosa. $\beta$-Galaktosidase yang dihasilkan dari mikroorganisme yang berbeda mempunyai karakteristik yang berbeda, diantaranya: berat molekul, rantai panjang protein, dan posisi sisi aktif. ${ }^{(32)} \beta$ Galaktosidase yang dihasilkan dari $L$. plantarum mempunyai donor proton $\mathrm{Glu}^{461}$ dan basa nukleofilik Glu ${ }^{537}{ }^{(24)}$ Proton donor dan nukleofilik spesifik dari $\beta$ galaktosidase mempunyai peranan dalam hidrolisis laktosa menjadi glukosa dan galaktosa. $^{(33)}$ Mekanisme katalitik $\beta$ galaktosidase adalah laktosa membentuk intermediet dengan nukleofil Glu 537 dan dibantu dengan asam (A: Glu 461 atau ion Magnesium). Selanjutnya Glu 461 mendonorkan proton dengan memberikan $\mathrm{H}^{+}$pada oksigen glikosidik yang disertai pemutusan ikatan glikosidik dan pelepasan glukosa. Langkah kedua adalah pembentukan intermediet transient triagonal oxocarbonium yang dibantu oleh basa (B: Glu 461) lalu terjadi protonasi dari Glu 461 yang dikatalisis air dan diakhiri dengan transfer galaktosil ke air atau gula lain. Jika akseptor berupa air maka akan terjadi proses hidrolisis sehingga terbentuk glukosa dan galaktosa. ${ }^{(34)}$

Kit enzimatik GOD-POD digunakan untuk determinasi peningkatan glukosa selama proses hiidrolisis laktosa pada susu UHT pada $50{ }^{\circ} \mathrm{C}$ selama 12 jam dengan interval waktu 1 jam. $\beta$-Galactosidase hasil dialisis yang ditambahkan adalah $4.8 \mathrm{U} / \mathrm{mL}$ susu. Kit GOD-POD adalah metoda uji glukosa secara enzimatik dan kolorimetrik. Prinsip uji ini adalah sebagai berikut (Cypress Diagnostics): 


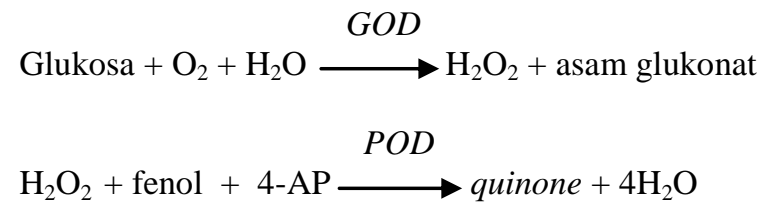

Glukosa dioksidasi dengan glucoseoxidase (GOD) menjadi asam glukonat dan hidrogen peroksida. Pembentukan hidrogen peroksida dideteksi dengan aseptor phenolaminophenazone chromogenic oxygen dengan bantuan peroxidase (POD) untuk menghasilkan senyawa quinone yang memberikan warna merah pada sampel, dan pengukuran dilakukan pada $\lambda 505 \mathrm{~nm}$. Semakin tinggi konsentrasi glukosa dalam sampel, semakin tinggi intensitas warna merah.

\section{KESIMPULAN}

Produksi $\beta$-galaktosidase L.plantarum B123 dengan purifikasi parsial/ hasil dialisis mengalami peningkatan. Kemurnian dan aktivitas spesifik $\beta$-galaktosidase $L$. plantarum B123 mengalami peningkatan setelah $\beta$-galaktosidase didialisis. Enzim $\beta$ galakosidase $L$. plantarum $\mathrm{B} 123$ hasil dialisis sebesar $4.8 \mathrm{U} / \mathrm{mL}$ dapat menghidrolisa $50 \%$ laktosa susu $U H T$ pada suhu $50{ }^{\circ} \mathrm{C}$ selama 6.08 jam. Disimpulkan bahwa $\beta$-galaktosidase $L$. plantarum B123 indigenos yang dipurifikasi secara parsial dapat digunakan sebagai penghidrolisa laktosa dalam memproduksi susu UHT rendah laktosa.

\section{UCAPAN TERIMA KASIH}

Penelitian ini didanai oleh proyek PKPP-RISTEK DIKTI 2012 dan DIPATEMATIK 2013, Bidang Mikrobiologi, Pusat Penelitian Biologi, LIPI. Penulis mengucapkan terima kasih kepada Neneng Karimaryati atas bantuan teknis selama penelitian.

\section{DAFTAR PUSTAKA}

1. P. Walstra, J.T.M. Wouters, T.J. Geurts. 2006. Dairy Science and Technology, 2end. ed. CRC Press-Taylor \& Francis Group, USA, 2006.

2. M. Montalto, V. Curigliano, L. Santoro, M. Vastola, G. Cammarota, R. Manna, A. Gasbarrini, G. Gasbarrni. Management and treatment of lactose malabsorption. World Journal of Gastroenterology. 12: 187-191 (2006).

3. P.S. Panesar, S. Kumari, R. Panesar. 2010. Potential applications of immobilized $\beta$-galactosidase in food processing industries. Review Article. Enzyme Research. 1-16 (2010).

4. P. Karasova, V. Spiwok, S. Mala, B. Kralova, and N.J. Beta-galactosidase activity in psychrotrophic microorganism and their potential use in food industry. Czech J Food Sci. 20 (2): 43-47 (2002).

5. C. Schwab, K.I. Sørensen, M.G. Ganzle. Heterologous expression of glycoside hydrolase family 2 and $42 \beta$ galactosidases of lactic acid bacteria in Lactococcus lactis. Systematic and Applied Microbiology. 33: 300-307 (2010).

6. E. Jurado, F. Camacho, G. Luzon, J.M. Vicaria. Enzyme and Microbial Technology. 31:300-309 (2002).

7. A. Jokar, A. Karbassi. In-house production of lactose-hydrolysed milk by $\beta$-galactosidase from Lactobacillus bulgaricus. J Agr Sci Tech. 13:577-584 (2011).

8. P. Katrolia, M. Zhang, Q. Yan, Z. Jiang, C. Song, L. Li. Characterization of thermostable family $42 \beta$-galactosidase ( $\beta$ galC) family from Thermotoga maritima showing efficient lactose hydrolysis. Food Chem. 125: 614-621 (2011). 
9. S. Erich, T. Anzmann, L. Fischer. Quantification of lactose using ion-pair RP-HPLC during enzymatic lactose hydrolysis of skim milk. Food Chem.135: 2393-2396 (2012).

10. A.I.R. Matute, M.C. Martinez, A. Montilla, A. Olano, P. Copovi, N. Corzo. Presence of mono-di-and galacto-oligosaccharides in commercial lactose-free UHT dairy products. Journal of Food Composition and Analysis. 28: 164-169 (2012).

11. E. Gheytanchi, F. Heshmati, B.K. Shargh, J. Nowroozi, F. Movahedzadeh. Study on $\beta$-galactosidase enzyme produced by isolated lactobacilli from milk and cheese. African Journal of Microbiology Research. 4(6):454-458 (2010).

12. S. Iqbal, T.H. Nguyen, T.T. Nguyen, T. Maischberger, D. Haltrich. $\beta$ Galactosidase from Lactobacillus plantarum WCFS1: biochemical characterization and formation of prebiotic galacto-oligosaccharides. Carbohydrate Research. 345:1408-1416 (2010).

13. P. Katrolia, M. Zhang, Q. Yan, Z. Jiang, C. Song, L. Li . 2011. Characterisation of thermostable family $42 \beta$ galactosidase ( $\beta$ galC) family from Thermotoga maritima showing efficient lactose hydrolysis. Food Chem. 125: 614-621.

14. S. Erich, T. Anzmann, L. Fischer L. 2012. Quantification of lactose using ion-pair RP-HPLC during enzymatic lactose hydrolysis of skim milk. Food Chem.. 135: 2393-2396.

15. J.M. Jay, M.J. Loessner, D.A. Golden. Modern Food Microbiology. $7^{\text {th }}$ Edition. USA: Springer Science and Business Media Inc, USA, (2005).

16. D. Wang, M. Sakakibara. Lactose hydrolysis and $\beta$-galactosidase activity in sonicated fermentation with
Lactobacillus strain. Ultrasonics Sonochem. 4: 255-261 (1997).

17. L.L. Lu, M Xiao, Y.M. Li, F.S. Wang. A novel transglycosylating $\beta$ galactosidase from Enterobacter cloacae B5. Process Biochem. 44: 232236 (2009).

18. M.M. Bradford. A rapid and sensitive method for the quantitation of microgram quantities of protein utilizing the principle of protein-dye binding. Anal Biochem. 72: 248-254 (1976).

19. R.K. Scopes. Protein Purification. RR Doneley and Sons, New York, 1993.

20. D. Kishore, M. Kayastha. A $\beta$ galactosidase from chick pea (Cicer arietinum) seeds: Its purification, biochemical properties and industrial application. Food Chem. 134: 11131122 (2012).

21. E.I. Fatchiyah, S. Arumingtyas, S. Widyarti, Rahayu. Molecular Biology. Analysis Basic. Penerbit Erlangga, Jakarta(ID), 2011. (in Indonesian).

22. M. Bintang. Biochemistry: Research Technique. Penerbit Erlangga, Jakarta (ID), 2011. (in Indonesian).

23. E. Gheytanchi, F. Heshmati, B.K. Shargh, J. Nowroozi, F. Movahedzadeh. Study on $\beta$-galactosidase enzyme produced by isolated Lactobacilli from milk and cheese. African Journal of Microbiology Research. 4:454-458 (2010).

24. C. Schwab, K.I. Sørensen, M.G. Ganzle. Heterologous expression of glycoside hydrolase family 2 and $42 \beta$ galactosidases of lactic acid bacteria in Lactococcus lactis. Systematic and Applied Microbiology. 33: 300-307 (2010).

25. T. Palmer Understanding Enzymes. $3^{\text {th }}$ Ed. Ellis Horwood, New York, 1991. 
26. A.L. Lehninger. Principles of Biochemistry. Elsevier Science, Amhrest, 2004.

27. M. Rhimi et al. Efficient bioconversion of lactose in milk and whey: immobilization and biochemical characterization of a $\beta$-galactosidase from the dairy Streptococcus thermophilus LMD9 strain. Res in Microbiol 161: 515-525 (2010).

28. CS. Kim, ES Ji, D.K. Oh. Expression and characterization of Kluyveromyces lactis $\beta$-galactosidase in Escherichia coli. Biotechnol Lett. 25: 1769-1774 (2003).

29. J. Szczodrak. 2000. Hydrolysis of lactose in whey permeate by immobilized $\beta$-galactosidase from Kluyveromyces fragilis. J Mol Catal B Enzymatic. 10: 631-637, (2000).

30. W. Aehle. Enzyme in industry. Production and Application. 3end completely revised ed. Verlag Gmbh \& Co.KGaA, Wiley-VCH, 2007.

31. L.L. Lu, M. Xiao, ZY Li, Y.M. Li, F.S. Wang. 2009. A novel transglycosylating $\beta$-galactosidase from Enterobacter cloacae B5. Process Biochem. 44: 232236 (2009).

32. J.M. Jay, M.J. Loessner, D.A. Golden. Modern Food Microbiology. $7^{\text {th }}$ end ed. Springer Science \& Business Media Inc., USA, 2005.

33. T.J. Britz, R.K. Robinson. Advanced Dairy Science and Technology. Blackwell Publishing Ltd., UK, 2008.

34. B.W. Matthews. The structure of E. coli $\beta$-galactosidase. $C R$ Biologies. 328 : 529-556, (2005). 
JKTI, Vol. 17, No. 2, Desember 2015 